\title{
Leaching of Solutes from an Intensively Managed Peat Soil to Surface Water
}

\author{
C. L. van Beek • P. Droogers • \\ H. A. van Hardeveld • \\ G. A. P. H. van den Eertwegh • G. L. Velthof • \\ O. Oenema
}

Received: 4 September 2006 / Accepted: 2 January 2007 / Published online: 14 March 2007

(C) Springer Science + Business Media B.V. 2007

\begin{abstract}
In many peat land areas in The Netherlands target concentrations for nitrogen $(\mathrm{N})$ and phosphorus (P) in surface water are exceeded. A considerable, but poorly quantified, fraction, of the $\mathrm{N}$ and $\mathrm{P}$ loading of surface water in these areas originate from the subsoil. Waterboards, responsible for the water management, are currently exploring options to improve surface water quality, whilst sustaining agricultural production. Therefore, insight into dynamics of nutrient pools in peat soils is required. The aim of this study was to measure concentration profiles $(0-12 \mathrm{~m})$ of the soil solution in an intensively managed grassland on peat soil and to explore the effects of a rise in surface water
\end{abstract}

At the time of study, H.A. van Hardeveld and G.A.P.H. van den Eertwegh were employed at Rijnland Water Board, P.O. Box 156, 2300 AD Leiden, The Netherlands.

C. L. van Beek $(\bowtie) \cdot$ G. L. Velthof $\cdot$ O. Oenema

Alterra, P.O. Box 47, 6700 AA Wageningen,

The Netherlands

e-mail: christy.vanbeek@wur.nl

P. Droogers

Future Water, Generaal Foulkesweg 28,

6703 BS Wageningen, The Netherlands

H. A. van Hardeveld

Delfland Water Board, P.O. Box 3061,

2601 DB Delft, The Netherlands

G. A. P. H. van den Eertwegh

Rivierenland Water Board, P.O. Box 599,

4000 AN Tiel, The Netherlands level on $\mathrm{N}$ and $\mathrm{P}$ loading of surface water, using budgeting approaches and two dimensional simulation modeling. The concentration profiles of $\mathrm{N}, \mathrm{P}$ and $\mathrm{Cl}$ reflect by the presence of nutrient-rich anaerobic peat and a nearly impermeable marine clay in the subsoil. Concentrations of $\mathrm{N}, \mathrm{P}$ and $\mathrm{Cl}$ tended to increase with depth till about $6 \mathrm{~m}$ and then decreased. In the top soil, inputs of $\mathrm{N}$ and $\mathrm{P}$ via fertilizers and animal manure were only partly retrieved in the soil solution, suggestion that biogeochemical processes, uptake and lateral transport processes had a dominant influence on dissolved $\mathrm{N}$ and $\mathrm{P}$. Exploring scenario simulations showed that major drainage fluxes passed through the peat layer that transported nutrients to adjacent surface water. Raising surface water levels with $20 \mathrm{~cm}$ suppresses this kind of nutrient loading of surface water by more than $30 \%$, but nutrient rich peat layers will remain persistent as a potential source of nutrients in surface water in many peat polders in the western part of The Netherlands.

Keywords Peat · Simulation · Soil solution · Suction cups $\cdot$ Surface water quality $\cdot$ Nutrient loads Nitrogen $\cdot$ Phosphorus

\section{Introduction}

In the western part of The Netherlands many polders with grassland on peat soils are situated that are used 
for intensive dairy farming. The grassland fields in these polders are intersected by shallow ditches for drainage of excess rainfall and land:water ratios range between 8:1 and 15:1 (De Boer 1982). Nitrogen (N) and phosphorus (P) loads to surface water are typically in the order of $40-85 \mathrm{~kg} \mathrm{~N} \mathrm{ha}^{-1} \mathrm{y}^{-1}$ and $1-6 \mathrm{~kg} \mathrm{P}$ $\mathrm{ha}^{-1} \mathrm{y}^{-1}$ (RIVM 2002) and contribute to the deterioration of surface water quality. A considerable part of the $\mathrm{N}$ and $\mathrm{P}$ loads is related to intensive dairy farming, but the peat soil itself may also contribute to the discharge of nutrients (Van Beek et al. 2004a).

Extensively managed peat soils can act as a source as well as a sink of nutrients, depending on peat type and drainage conditions (Heathwaite 1991; Peverly 1982; Wieder and Lang 1984). Intensively managed peat soils are generally considered as a source of nutrients, because the indigenous peat can contain considerable amounts of nutrients that are available for leaching (Heathwaite 1990). For intensively managed grasslands on peat soils various sources of nutrients may contribute to surface water loading, viz. fertilizers, manure, cattle droppings, seepage, atmospheric deposition, mineralization of soil organic matter and dissolved nutrients in the subsoil. The quantification of the contribution of each individual source of nutrients is complex, because different sources are hard to discriminate from each other and because the relations between sources and transport processes to surface water are still poorly understood.

In general, shallow groundwater levels coincide with relatively high $\mathrm{N}$ and $\mathrm{P}$ loads to surface water in agricultural areas (RIVM 2002), because of the small water storage capacity of the soil and because drainage water passes through shallow soil layers. Shallow soil layers are commonly enriched with nutrients from agricultural inputs, and it is usually assumed that drainage of these shallow, enriched soil layers has a large impact on $\mathrm{N}$ and $\mathrm{P}$ loading of surface water. For peat soils however, this generality may not hold as (1) a major part of the $\mathrm{N}$ surpluses at the soil surface is quickly denitrified (De Klein and Logtestijn 1994; Koops et al. 1996) and (2) indigenous peat layers may contain large amounts of nutrients that can contribute significantly to the $\mathrm{N}$ and $\mathrm{P}$ loading of surface water (Heathwaite 1991).

Drainage of peat soils is a prerequisite for intensive agricultural management, but also enhances subsidence of peat soils (Schothorst 1977). Subsidence of the surface necessitates the lowering of surface water levels and these intimately linked processes may continue until all peat has been oxidized. Subsidence contributes to a sequence of side effects, including damage of infrastructure and increased risks for salt water intrusion and flooding. Water boards are currently exploring options to raise surface water levels to slow down subsidence, whilst sustaining agricultural production. Therefore, insights into mechanisms of nutrient leaching from peat soils under present and possible future drainage conditions are required.

The objectives of the study presented in this paper were to analyze current distributions of nutrients in shallow soil layers of an intensively managed peat soil and to assess possible impacts of surface water rising on nutrient leaching to surface water. Monitoring results of the composition and distribution of solutes in the soil solution of an intensively managed peat land are presented, along with results of simulation modeling of soil water movements in the upper $3.25 \mathrm{~m}$ and flow patterns in soil, to assess the implications of surface water rising on transport of solutes from shallow soil layers to surface water.

\section{Materials and Methods}

\subsection{Site Description}

The study was carried out in the "Vlietpolder" in the Western part of The Netherlands ( $\left.52^{\circ} 10^{\prime} \mathrm{N} ; 4^{\circ} 36^{\prime} \mathrm{E}\right)$. The Vlietpolder is 200 ha in size and at present has a surface level of about $2 \mathrm{~m}$ below mean sea level. All fields in the Vlietpolder (65) are intensively used for dairy farming (grassland) and are intersected by shallow ditches and the land-water ratio is about 10:1. The soil consists of a man-made topsoil of about $30 \mathrm{~cm}$, oxidized eutrophic peat $(0.3-1 \mathrm{~m})$, reduced eutrophic peat $(1-3 \mathrm{~m})$, calcareous marine deposits containing light and heavy clay (3-9 m) and Pleistocene sands (>9 m, Fig. 1). The hydrology of the Vlietpolder is described by Meinardi (2004), and can be characterized by decreasing hydraulic heads with depth with relative small gradients in the Holocene peat and clay and a relative large gradient in the Pleistocene sands. Groundwater levels in the middle of the fields fluctuate between 0 and $100 \mathrm{~cm}$ below soil surface. Groundwater recharge was estimated at $25 \mathrm{~mm} \mathrm{y}^{-1}$. 
One field (approximately $40 \times 400 \mathrm{~m}$ ) was selected for intensive monitoring and is referred to as experimental field. The experimental field was surrounded by ditches at three sides. The field was made concave to increase surface drainage by dragging soil from the sides of the field towards the middle and nowadays the field slightly declines from the centre towards the ditch $\left(\sim 2 \mathrm{~cm} \mathrm{~m}^{-1}\right)$. Surface water levels were kept at about $58 \mathrm{~cm}$ below soil surface during winter and $48 \mathrm{~cm}$ below soil surface during summer. In one dead-end ditch a flow meter was placed (Fig. 1) and ditch discharge was determined, as described in Van Beek et al. (2004a). During the experimental period total $\mathrm{N}$ and $\mathrm{P}$ inputs in the Vlietpolder were about $450 \mathrm{~kg} \mathrm{~N} \mathrm{ha}^{-1} \mathrm{y}^{-1}$ and $35 \mathrm{~kg}$ $\mathrm{P} \mathrm{ha}^{-1} \mathrm{y}^{-1}$ via mineral fertilizer, cattle slurry, manure and urine of grazing cattle, atmospheric deposition and application of slush from ditch cleaning, of which most was applied in spring and early summer (Van Beek et al. 2003a).

\subsection{Soil Balances}

To relate above ground inputs to below ground processes we analyzed two kinds of element balances; the soil surface balance (SSB) and the soil system balance (SSysB). The SSB accounted for all inputs and outputs at the soil surface viz. inputs via atmospheric deposition, applications of fertilizers, slurry and cattle droppings, and outputs via harvests of mown and grazed grass. The SSysB is a more elaborated soil balance and also accounts for $\mathrm{NH}_{3}$ volatilization, denitrification, leaching and net mineralization. The surplus of the SSB gives the net balance at the soil surface and is a descriptor of the nutrient management at field level. The net balance of the SSysB is an indicator of the net depletion or accrual of the soil system, and is also an indicator of our process understanding. As the SSysB accounts for all inputs and outputs of the soil system, the net balance is a measure for the correctness of balance entries, provided that changes in soil storage are limited (Oenema and Heinen 1999). The SSB and the SSysB of the experimental field were constructed for $\mathrm{N}, \mathrm{P}$ and $\mathrm{Cl}$, using results from previous studies on the same site (Van Beek et al. 2003a, 2004a, b) complemented with results from the present study. We used the methodology described in Van Beek et al. (2003a) which briefly included that so-called grassland calendars on which farmers recorded day-to-day field activities were analyzed. Inputs and outputs of N, P and $\mathrm{Cl}$ were calculated based on experimentally quantified contents of $\mathrm{N}, \mathrm{P}$ and $\mathrm{Cl}$ in manure and grass and on known relations between grazing intensity, excretion and dry matter uptake of cows. Volatilization of $\mathrm{NH}_{3}$ from the experimental field was estimated at $7 \mathrm{~kg} \mathrm{~N} \mathrm{ha}^{-1} \mathrm{y}^{-1}$, based on an $8 \%$ emission from excreta of grazing cattle (Bussink 1992).

\subsection{Soil Solution}

In previous research on diagenetic properties of the Vlietpolder using natural abundance ratios of ${ }^{2} \mathrm{H}$ and ${ }^{18} \mathrm{O}$ it was concluded that the groundwater system below about $3 \mathrm{~m}$ below soil surface had little interaction with the topsoil for the past 1,000 years (Meinardi 2004). Therefore, more emphasis was put
Fig. 1 Location of the Vlietpolder (left), the experimental field (centre) with ceramic suction cups (triangles), groundwater probe (asterisk) and meteorological station $(M)$, and crosssection of the soil profile of the Vlietpolder and Polder Oudendijk

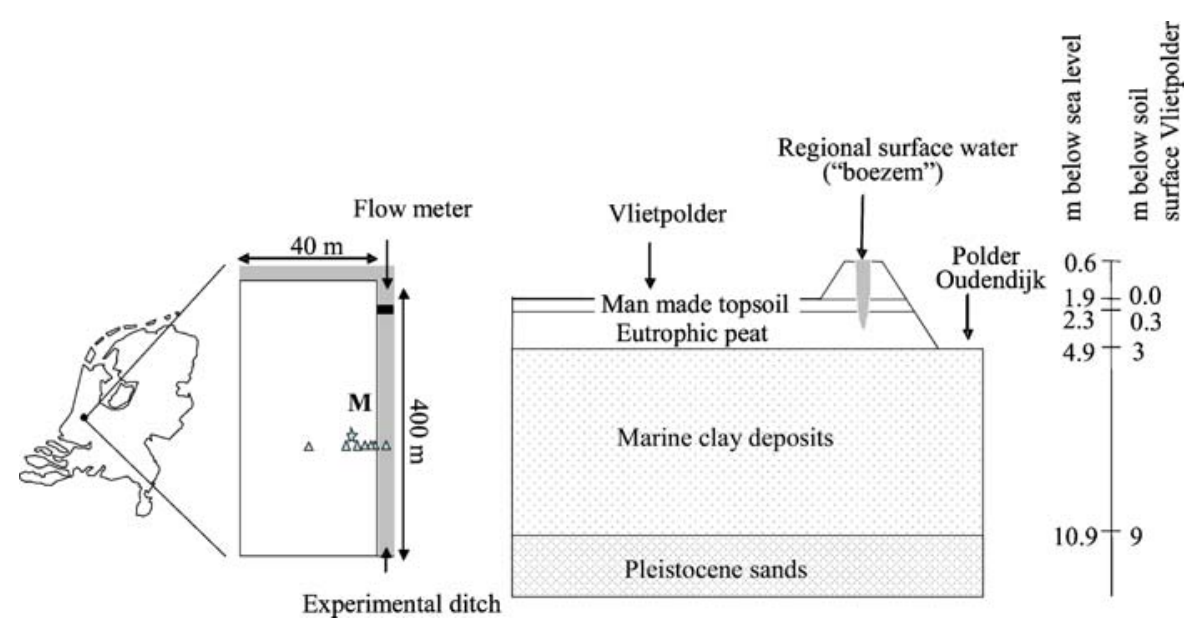


on the upper soil layers than on the deeper soil layers. The soil solution was sampled using ceramic suction cups which were inserted in triplicate in a transect perpendicular to the ditch at $0.15,0.25,0.35,0.50$, 0.70 and $1.20 \mathrm{~m}$ below surface and at $1,2,4,7,10$, $20 \mathrm{~m}$ from the ditch, where $20 \mathrm{~m}$ equals the middle of the field (Fig. 1). Below the ditch ceramic suction cups were inserted at 78 and $106 \mathrm{~cm}$ below soil surface. With ceramic suction cups the mobile fraction of the soil solution is sampled (Corwin 2002). From October 2001 till September 2002, every 2 weeks vacuum bottles (approximately $-90 \mathrm{kPa}$ ) were connected to the suction cups to collect mixed water samples (one per location). Additionally, groundwater samples were taken using groundwater tubes with $1 \mathrm{~m}$ filters at 1, 3, 6,9 and $12 \mathrm{~m}$ below soil surface. The groundwater tubes were placed in four fields in the Vlietpolder and samples were taken four times a year from December 1999 to December 2002. Water samples were analyzed for $\mathrm{NH}_{4}, \mathrm{Cl}$, ortho-P, total-P, $\mathrm{NO}_{3}+\mathrm{NO}_{2}, \mathrm{NO}_{2}$, $\mathrm{N}-\mathrm{Kjeldahl}, \mathrm{SO}_{4}$, and $\mathrm{pH}$ by continuous flow analysis according to ISO 5663. Total-N was calculated as the sum of N-Kjeldahl and $\mathrm{NO}_{3}+\mathrm{NO}_{2}$. Spatial interpolations between ceramic suction cups were made by inverse squared distance (Davis 1986).

\subsection{Mathematical Simulations}

A representative cross-section of the experimental field (20 m length, $3.25 \mathrm{~m}$ depth) was simulated in HYDRUS2D to analyze the behavior of water and tracer through the shallow soil solution. The HYDRUS2D program is a finite element model for simulating the movement of water, heat, and multiple solutes in variably saturated media (Simunek et al. 1999). The experimental field was schematized by 989 triangle elements taking into account the slight decline of the field towards the ditch. Because temporal dynamics of the infiltration rates were largely unknown, and because the clayey layer at 3$9 \mathrm{~m}$ had a very low permeability, the lower boundary was assumed impermeable (no flow). The left boundary equaled the middle of the field and was regarded as the water divide.

The aim of the mathematical simulations was to explore the behavior of water and solutes for different hydrological scenarios rather than to give an exact representation of the field measurements. Hydraulic properties were measured in duplicate samples at a depth of $30-70 \mathrm{~cm}$ below soil surface and were assumed representative for the whole profile. The dimensionless anisotropy factor $\mathrm{K}^{\mathrm{A}}$ was set at two to account for the horizontal orientation of the deposits and to allow surface run-off. Two dimensionless conservative tracers (initial concentration $=100$ ) were introduced to the model that were constantly released to simulate a constant source. The tracers were spatially located in such a way that water movements affecting solutes in the peat layer could be discriminated from water movements affecting solutes originating from agricultural practices.

Simulations of transport of water and solutes were run for 30 years using actual weather data from a nearby $(50 \mathrm{~km})$ weather station from 1974 onwards. The numerical stability of water and tracer was good $(<2.1 \%)$. We present the results of three runs. The first run, run 1 , resembled the current conditions and was regarded as the reference situation. In the second run, run 2 , surface water levels were raised by $20 \mathrm{~cm}$, and in the third run, run 3 , an additional downwards seepage of $1 \mathrm{~mm} \mathrm{~d}^{-1}$ was added to the second run, because downwards seepage is likely to increase when surface water levels are raised. For each run cumulative leaching rates in units of a conservative tracer are presented.

\section{Results}

\subsection{Inputs of $\mathrm{N}, \mathrm{P}$ and $\mathrm{Cl}$ at the Soil Surface}

For $\mathrm{N}$ and $\mathrm{Cl}, \mathrm{SSB}$ surpluses were 105 and $38 \mathrm{~kg}$ $\mathrm{ha}^{-1} \mathrm{y}^{-1}$, respectively. Major balance entries were mineral fertilizers and slurry application (Table 1). For P no surplus was calculated. The SSysB showed surpluses of $95 \mathrm{~kg} \mathrm{~N} \mathrm{ha}^{-1} \mathrm{y}^{-1}$ and $8 \mathrm{~kg} \mathrm{P} \mathrm{ha}^{-1} \mathrm{y}^{-1}$ and a deficit of $12 \mathrm{~kg} \mathrm{ha}^{-1} \mathrm{y}^{-1}$ for $\mathrm{Cl}$. The SSysB surpluses were less than $10 \%$ of the total turnover for $\mathrm{N}, \mathrm{P}$ and $\mathrm{Cl}$. These relatively small surpluses on the SSysB indicate that we likely did not overlook major processes affecting transport of solutes in the shallow soil solution of the experimental field.

\subsection{Concentrations of Solutes in the Soil Solution}

Solute concentrations in the shallow soil showed large spatial variations and relatively little variation in time. In general, we found high concentrations of solutes 
Table 1 Soil surface balance and soil system balances of $\mathrm{N}, \mathrm{P}$ and $\mathrm{Cl}$ for the experimental field in $2002\left(\mathrm{~kg} \mathrm{ha}^{-1} \mathrm{y}^{-1}\right)$

\begin{tabular}{|c|c|c|c|c|c|c|}
\hline & & & Soil surface balance & $\mathrm{N}$ & $\mathrm{P}$ & $\mathrm{Cl}$ \\
\hline \multirow{14}{*}{$\begin{array}{l}\text { Soil } \\
\text { system } \\
\text { balance }\end{array}$} & \multirow{14}{*}{$\begin{array}{l}\text { Soil } \\
\text { surface } \\
\text { balance }\end{array}$} & \multirow[t]{4}{*}{ In } & Mineral fertilizer ${ }^{\mathrm{a}}$ & 159 & 0 & 11 \\
\hline & & & Atmospheric deposition $^{\mathrm{b}}$ & 31 & & 71 \\
\hline & & & Slurry application ${ }^{\mathrm{c}}$ & 159 & 22 & 81 \\
\hline & & & Dung and urine of grazing cattle ${ }^{c}$ & 87 & 9 & 33 \\
\hline & & \multirow[t]{2}{*}{ Out } & Mown grass ${ }^{\mathrm{d}}$ & -231 & -24 & -79 \\
\hline & & & Grazing $^{\mathrm{d}}$ & -100 & -10 & -79 \\
\hline & & Surplus SSB & & 105 & -3 & 38 \\
\hline & & \multirow[t]{2}{*}{ In } & Supply from peat layer ${ }^{\mathrm{e}}$ & 8 & 3 & 120 \\
\hline & & & Mineralization of soil organic matter & 244 & 10 & $<1$ \\
\hline & & \multirow[t]{4}{*}{ Out } & Leaching to surface water & -38 & -2 & -170 \\
\hline & & & Groundwater recharge & -4 & $<1$ & $<1$ \\
\hline & & & Denitrification $^{\mathrm{f}}$ & -213 & 0 & 0 \\
\hline & & & $\mathrm{NH}_{3}$ volatilization & -7 & 0 & 0 \\
\hline & & \multicolumn{2}{|l|}{ Surplus SsysB } & 95 & 8 & -12 \\
\hline
\end{tabular}

${ }^{\mathrm{a}} \mathrm{CAN}$ (Calcium Ammonium Nitrate, $27 \% \mathrm{~N}, 2 \% \mathrm{Cl}$ ).

${ }^{\mathrm{b}}$ National Rainwater Monitoring Programme.

${ }^{\mathrm{c}}$ Average $\mathrm{N}$ and $\mathrm{P}$ contents of manure were $4.78 \mathrm{~kg} \mathrm{~N} \mathrm{~m}^{-3} \mathrm{dm}$ and $0.73 \mathrm{~kg} \mathrm{P} \mathrm{m}^{-3} \mathrm{dm}$. Cl contents were taken from Pratt (1978) and equaled $2 \%$ and were comparable to unpublished Dutch results.

${ }^{\mathrm{d}}$ Average N, $\mathrm{P}$ and $\mathrm{Cl}$ contents of grass samples were $0.035 \mathrm{~g} \mathrm{~N} \mathrm{~g}^{-1} \mathrm{dm}, 0.0038 \mathrm{~g} \mathrm{P} \mathrm{g}^{-1} \mathrm{dm}$ and $0.016 \mathrm{~g} \mathrm{Cl} \mathrm{g}^{-1} \mathrm{dm}$.

${ }^{\mathrm{e}}$ For $\mathrm{N}$ and $\mathrm{P}$ taken from Van Beek et al. (2004a). In the reduced peat layer N:Cl ratios were about 1:15 (Fig. 3) and this ratio was used to estimate the $\mathrm{Cl}$ supply from the $\mathrm{N}$ supply.

${ }^{\mathrm{f}}$ Total $\mathrm{N}$ losses through denitrification were estimated at $126-213 \mathrm{~kg} \mathrm{~N} \mathrm{ha}^{-1} \mathrm{y}^{-1}$ (Van Beek et al. 2004b). To account for underestimations due to methodological difficulties (Bollmann and Conrad 1997) we used the upper range.

below the ditch that leveled-off in a bell shaped curve towards the middle of the field. For $\mathrm{Cl}$ this 'high concentration bell' was most apparent with concentrations of $>100 \mathrm{mg}^{-1}$ below the ditch that decreased to about $20 \mathrm{mg}^{-1}$ in the middle of the field (Fig. 2). For total-N, $\mathrm{NH}_{4}$, total-P and ortho-P comparable spatial distributions were found (not shown).

Figure 3 shows depth profiles of solute concentrations in the soil solution, using the ceramic suction cups for $\mathrm{Cl}$, total-P, $\mathrm{NH}_{4}$ and total-N. Chloride, total$\mathrm{P}$ and $\mathrm{NH}_{4}$ showed a strong increase of concentration with depth. For dissolved total-N high concentrations were found occasionally in the upper two ceramic suction cups that resulted in large standard deviations. $\mathrm{NO}_{3}-\mathrm{N}$ concentrations in the soil solution were most often below the detection limit of $0.05 \mathrm{mg} \mathrm{N}^{-1}$ and were therefore omitted from further analysis. The groundwater probes showed a continuation of the concentration increase with depth until about $6 \mathrm{~m}$ below soil surface for all solutes. At greater depth (6-12 $\mathrm{m}$ below soil surface) solute concentrations decreased (Fig. 4). With the groundwater tubes different water was sampled than with the ceramic suction cups, i.e. with the groundwater tubes mobile water in the saturated zone was sampled, while with the ceramic suction cups water was extracted from fast-flowing pores in the vadose zone. Consequently, we could not directly relate the results of the ceramic suction cups with those from the groundwater tubes, although there was a reasonable correspondence (compare Figs. 3 and 4).

\subsection{Model Performance}

The model simulations were validated on measured discharge rates of the ditch and on $\mathrm{Cl}$ concentrations in the soil solution. The simulated drainage and surface run-off agreed within 3\% of the measured ditch discharge rates on a longer time-span (2 years). On a daily basis, however, response times of drainage and infiltration were overestimated by the model, i.e. the measurements showed less fluctuations in drainage 
16-10-2001

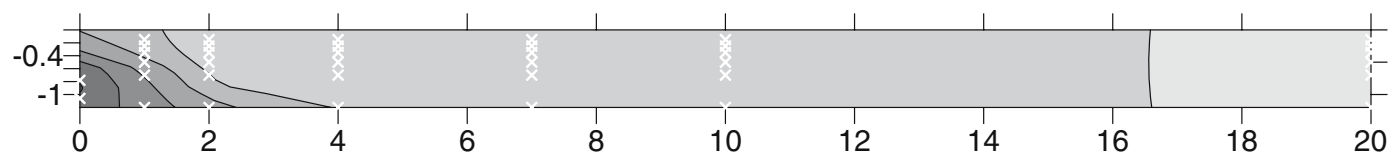

01-11-2001

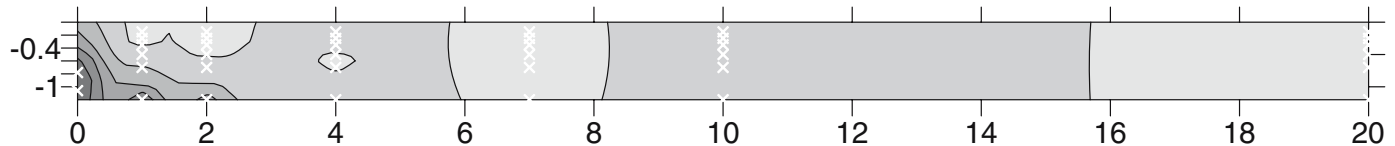

04-12-2001
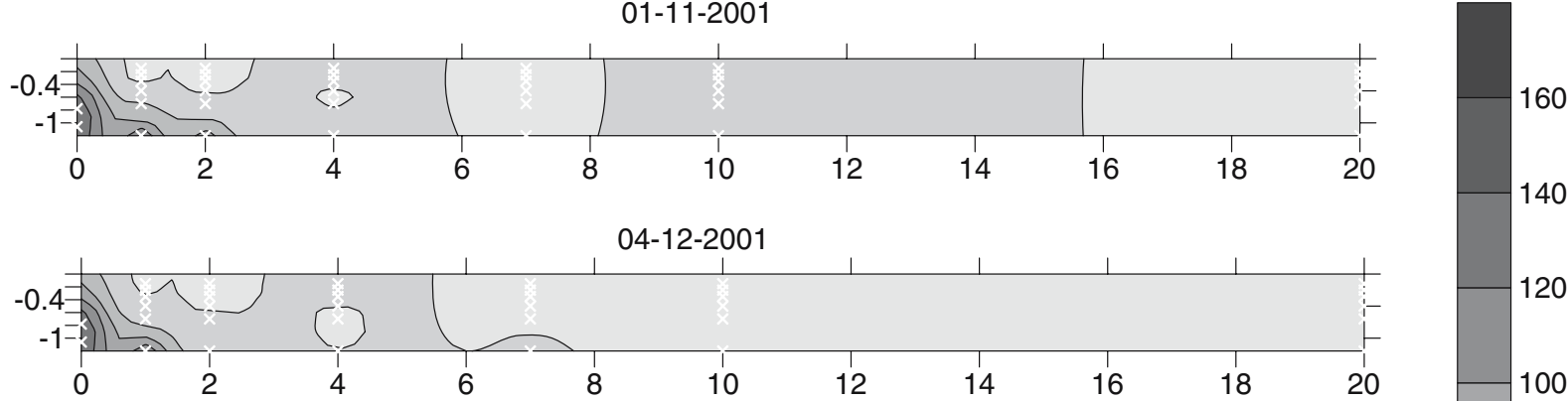

27-03-2002

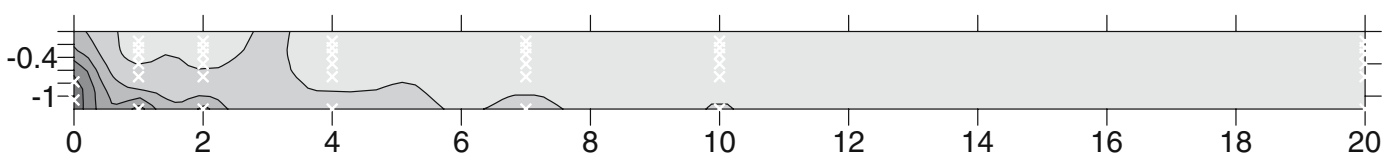

31-05-2002

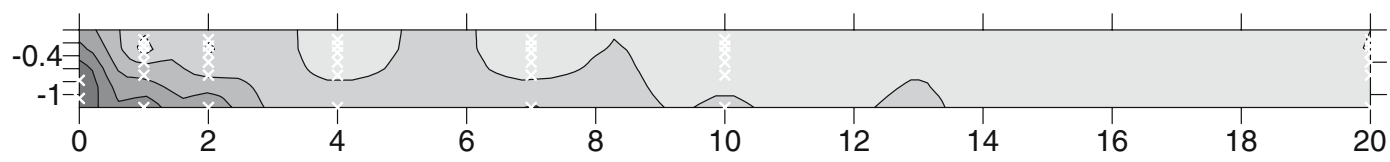

28-08-2002

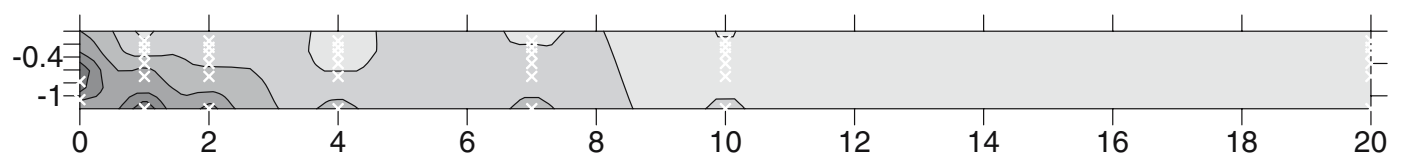

Fig. 2 Contour plots of $\mathrm{Cl}$ concentrations in the soil solution. Concentrations increase from light to dark and white asterisks show locations of the ceramic suction cups. On the $x$-axes the

distance from the ditch is shown and on the $y$-axes the depth below soil surface $(m)$. The ditch is located in the upper left corner

and infiltration rates than the simulation model (Droogers et al. 2005). There were three possible explanations for these deviations: (1) the flow meter was placed at the end of the ditch $(400 \mathrm{~m})$, while the model simulated a cross-section of one side of the ditch, (2) in the model simulation the ditch water level was assumed constant, while in practice some fluctuations were allowed that could buffer fluctuations in drainage and infiltration rates, and (3) effects of hysteresis were not taken into account in the simulations, which could have caused overestimation of infiltration rates. Nonetheless, simulated tracer concentrations agreed reasonable with measured $\mathrm{Cl}$ concentrations when averaged over distance $\left(R^{2}=\right.$ 0.74 , Fig. 5) and consequently it was concluded that the performance of HYDRUS2D to simulate movement of water and conservative solutes in the reference situation of the Vlietpolder was adequate to explore the possible effects of various scenarios.

\subsection{Scenario Analysis}

The reference run (run 1) showed a strong horizontal orientation of flow pathways during discharge periods. In dry periods (e.g. August and September) some infiltration of ditch water and 


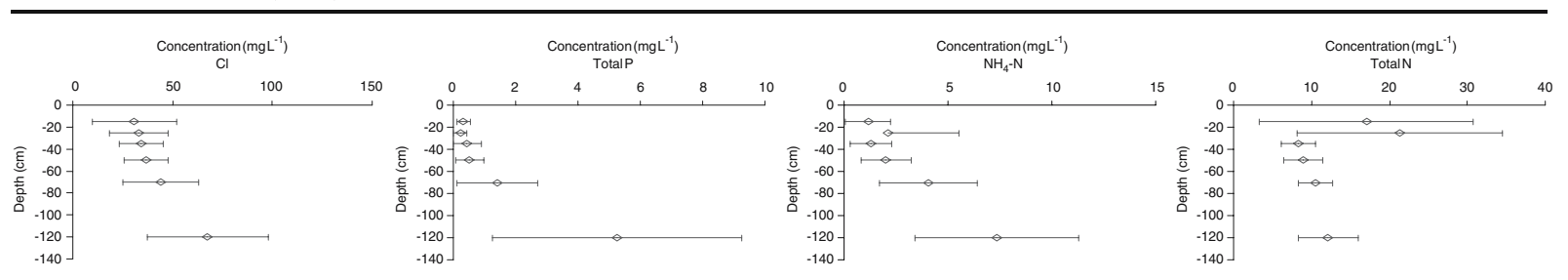

Fig. 3 Concentration profiles with depth measured with the ceramic suction cups. Error bars show standard deviations $(n=6-148)$

little water movement in the middle of the field was simulated (Fig. 6). The horizontal orientation of discharge pathways was maintained when ditch water levels were increased in run 2 and when an additional groundwater recharge of $1 \mathrm{~mm} \mathrm{~d}^{-1}$ (i.e. much higher than the estimated $25 \mathrm{~mm} \mathrm{y}^{-1}$ ) was introduced in run 3 (not shown). Also, the spatial distribution of the tracer hardly changed in 30 years of simulation. In the reference situation (run 1) leaching of the peat layer to the surface water was about 70 units tracer $y^{-1}$. The majority (about $90 \%$ ) of the tracer was leached during winter, which is visible in Fig. 7 by the stair wise increase of cumulative leaching. An increase of the ditch water level with $20 \mathrm{~cm}$ (run 2) resulted in an average decrease of $30 \%$ in leaching of solutes originating from the peat layer over 30 years. When an additional increase of downwards seepage was taken into account in run 3 the decrease in surface water loading equaled $73 \%$ (Fig. 7).

\section{Discussion}

The Dutch peat soils are rather unique in the sense that there are only few other places in the world where peat lands are used for intensive agriculture. In literature, most studies on peat soils refer to extensively managed wetlands, and therefore are difficult to compare with our results. Nonetheless, several authors reported significant leaching losses from peat soils when drained irrespective of fertilization (Heathwaite
1990; Nilsson and Lundin 1996; Wieder and Lang 1984). Heathwaite $(1990,1991)$ showed that a substantial nutrient source is stored within the peat and undrained peat samples in general contained more nutrients per unit of dry weight than drained peat samples.

Grasslands management on peat soils is almost as intensive as on mineral soils in The Netherlands (Reijneveld et al. 2000). In fertilizer recommendations, allowance is made for supply of nutrients by the soil, but this is not always done in practice. Farmers consider the nutrient release from the soil unpredictable and point at the man-made topsoil consisting of sand, clay and wastes. As a consequence, the inputs of $\mathrm{N}$ and $\mathrm{P}$ via fertilizers and animal manure are relatively high, but decreasing because of the manure policy (RIVM 2002), and have contributed to the nutrient enrichment of the top soil. This enrichment of the topsoil combined with the shallow and lateral flow of drainage water contributes to the nutrient enrichment of the surface waters in the Vlietpolder. However, our results show that also the nutrient rich subsoil has a strong impact on the composition of the soil solution (Figs. 2, 3 and 4) and on the nutrient leaching to surface water.

For the experimental field, surpluses were observed for $\mathrm{N}$ and $\mathrm{Cl}$ on the SSB and SSysB (Table 1). These surpluses were only partly retrieved in the shallow soil solution of the topsoil. In general, solute concentrations in the shallow soil solution increased in the direction of the ditch (Fig. 2) and with depth
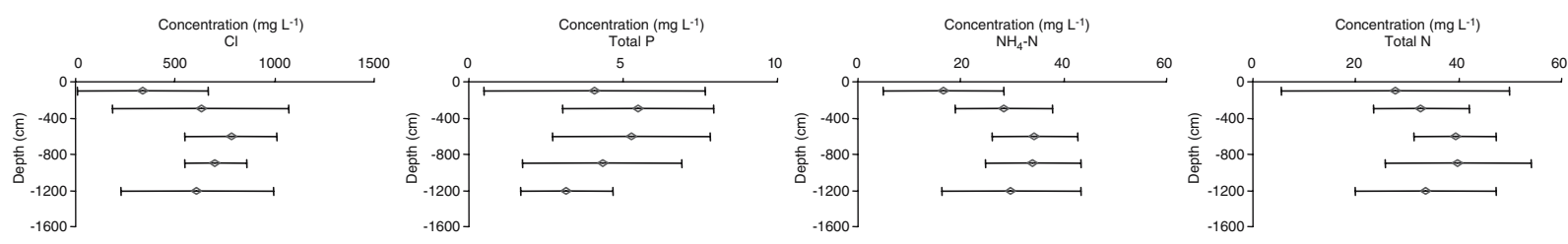

Fig. 4 Concentration profiles with depth measured with groundwater tubes. Error bars show standard deviations ( $n=4-16)$ 


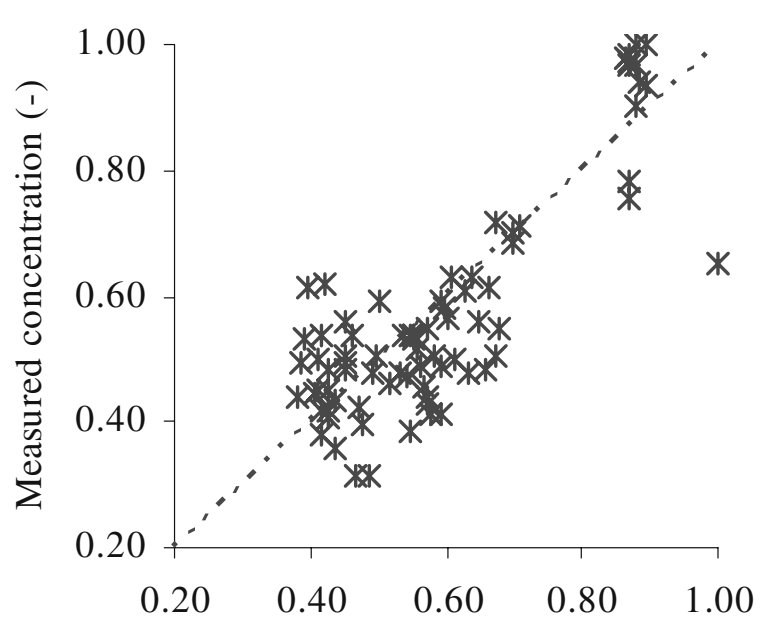

Simulated concentration (-)

Fig. 5 Measured and simulated $\mathrm{Cl}$ concentrations at several depths $(0,25 ; 0.50$ and $1.20 \mathrm{~m}$ below soil surface) averaged over five distances from the ditch (1, 2, 4, 7 and $10 \mathrm{~m})$. Results are converted to dimensionless units and dashed line is 1:1 line

(Fig. 3) until about $6 \mathrm{~m}$ below soil surface (Fig. 4). For total-N relatively high concentrations were found at 15 and $25 \mathrm{~cm}$ below soil surface with high standard errors (Fig. 3). These high concentrations were probably caused by fertilizer application, but it was not possible to relate events of fertilizer application directly to moments of increased $\mathrm{N}$ concentrations in the soil solution. Apparently effects of agricultural inputs on solute concentrations in the soil solution were masked by biochemical processes (mineralization, nitrification and denitrification), meteorological conditions and lateral transport processes.

Denitrification and mineralization likely have a strong effect on dissolved $\mathrm{N}$ concentrations as the magnitude of these flows was relatively large (Table 1). The spatial pattern of $\mathrm{N}$ concentrations in the soil solution may also relate to spatial variation in denitrification. On a nearby grassland, Velthof et al. (1996) observed a strong spatial relation between nitrous oxide $\left(\mathrm{N}_{2} \mathrm{O}\right)$ emissions and distance to the ditch. As denitrification is a major source of $\mathrm{N}_{2} \mathrm{O}$ in peat soil (Koops et al. 1997) it may suggest that rates of denitrification are also dependent on the distance to the ditch. However, no spatial dependence of denitrification rates were observed by Van Beek et al. (2004b) at the study site. Therefore, we presume that the observed spatial distribution of solutes including $\mathrm{N}$ was mainly caused by a combination of drainage and upwards diffusion of solutes as described by Fraser et al. (2001) and Giller and Wheeler (1986) for extensively used peat lands. These transport processes led to the development of a rainwater lens in the
Fig. 6 Simulated flow pathways at some typical moments for a representative cross-section in the experimental field $(20 \mathrm{~m}$ length, $3.25 \mathrm{~m}$ depth)
1 aug 1998

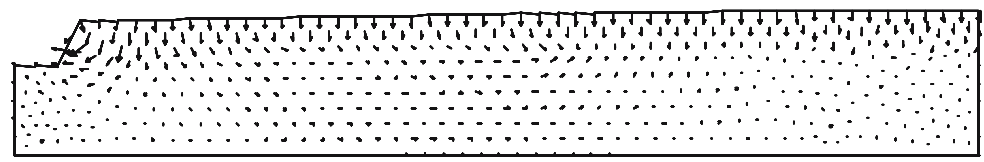

15 aug 1998

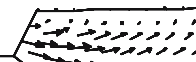

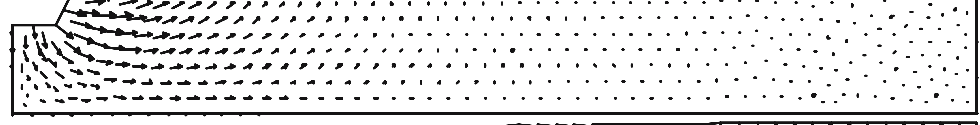

1 sep 1998

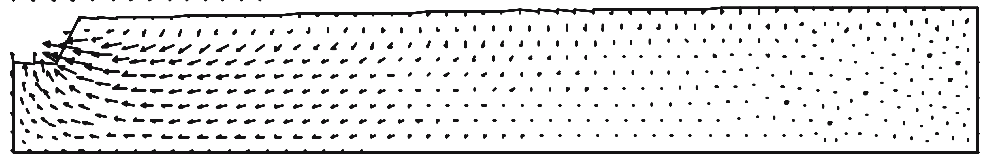

15 sep 1998

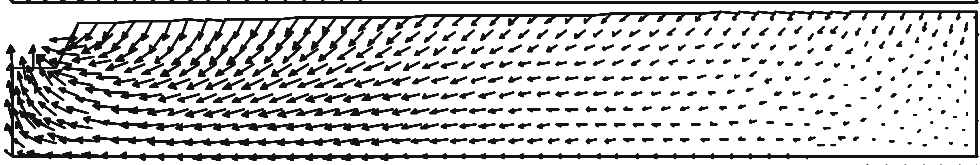

1 oct 1998

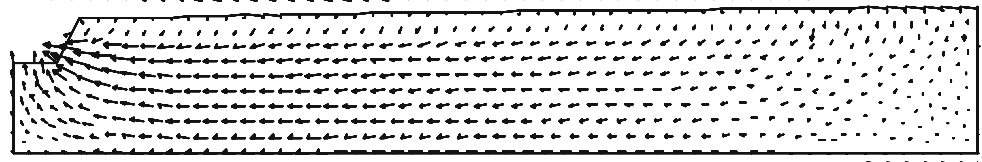

15 oct 1998 
Fig. 7 Cumulative leaching of an inert tracer representing the solutes in the peat layer for different scenarios. Run $1=$ reference situation, run $2=+20 \mathrm{~cm}$ surface water level, run $3=$ run $2+$ downwards seepage of $1 \mathrm{~mm} \mathrm{~d}^{-1}$

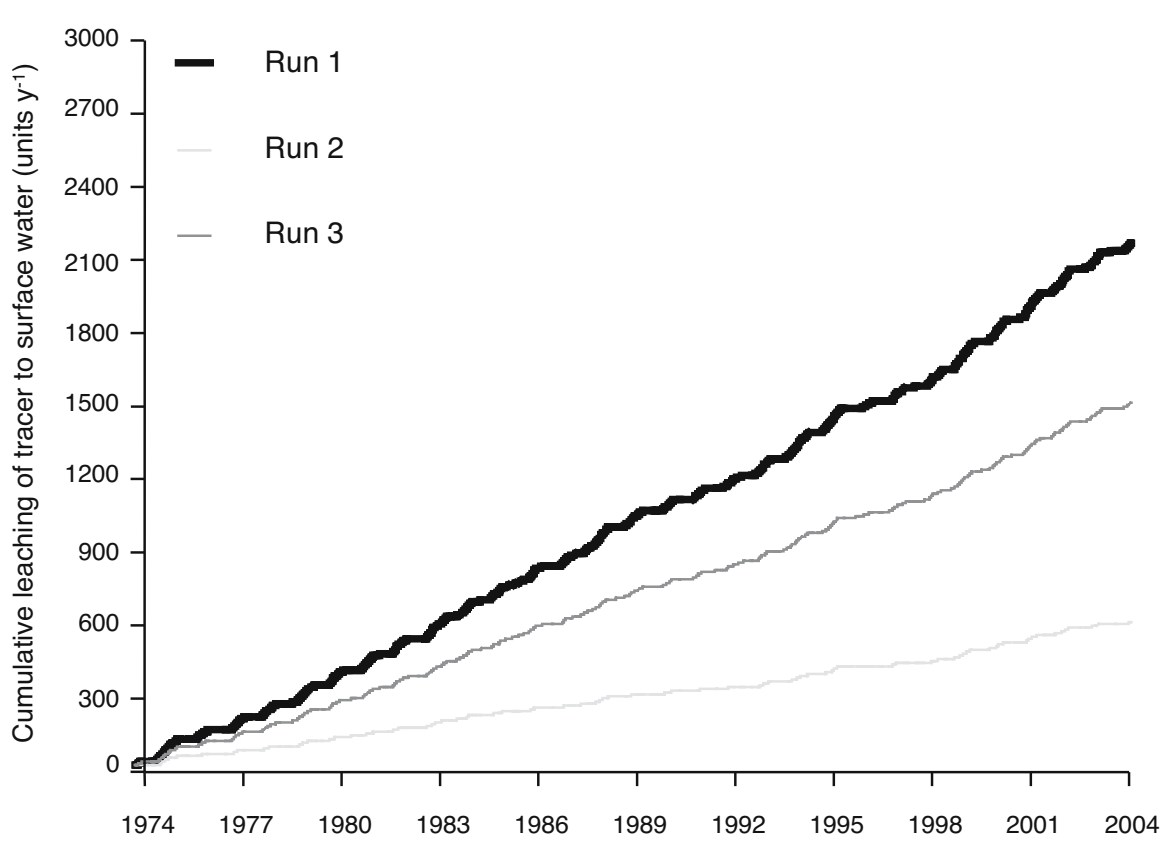

middle of the field as was demonstrated also by Wassen and Joosten (1996) and Poot and Schot (2000) for shallow soils. In a rainwater lens the indigenous soil solution is gradually replaced by rainwater with lower concentrations and eventually the rainwater lens floats on top of the indigenous soil solution.

In the Vlietpolder denitrification rates were governed by $\mathrm{NO}_{3}$ contents in soil (Van Beek et al. 2004b). Total $\mathrm{N}$ mineralization from soil organic matter in the rootable zone in the Vlietpolder was estimated at $244 \mathrm{~kg} \mathrm{ha}^{-1} \mathrm{y}^{-1}$ (Van Beek et al. 2004a). Apparently, a large fraction of the mineralized $\mathrm{NH}_{4}^{+}$ was quickly taken up by grass and/or nitrified to $\mathrm{NO}_{3}^{-}$, and subsequently nearly completely denitrified, considering the fact that $\mathrm{NO}_{3}^{-}$concentrations in the soil solution were generally below the detection limit. This intimate linkage of $\mathrm{N}$ processes was supported by the presence of ample anaerobic micro sites in the upper oxidized zone of the experimental field, as measured with $\mathrm{O}_{2}$ micro sensor (unpublished results Dr K. Rappoldt). Hence, little nitrate was leached to the surface water.

Our results suggest that a major part of the soil $\mathrm{N}$ that leached to surface water was $\mathrm{NH}_{4}-\mathrm{N}$ and dissolved organic $\mathrm{N}$ that originated from the deeper, reduced peat layers, and from surficial run-off. This suggestion was supported by the $\mathrm{Cl}$ concentrations of the ditch water. Chloride concentrations in ditch water were on average $118 \pm 58 \mathrm{mg}^{-1} \quad(n=126)$. Using a simple mixing model with $\mathrm{Cl}$ concentrations of $150 \mathrm{mg}^{-1}$ just below the ditch, $80 \mathrm{mg}^{-1}$ just besides the ditch and $40 \mathrm{mg} \mathrm{l}^{-1}$ at the soil surface (see Fig. 2) we calculated that more than $50 \%$ of the $\mathrm{Cl}$ in surface water originates from the high concentrations just below the ditch.

This study exemplifies that the presence of eutrophic peat and marine clay in the soil profile and hydrological conditions strongly affect the distribution of solutes in the soil solution, and thereby the response of nutrient leaching on measures to reduce nutrient leaching. The simulation results demonstrated that increasing surface water levels resulted in decreasing loads of a conservative tracer to surface water (Fig. 7). This effect can be explained by the fact that increasing the surface water level will eventually result in shallower drainage pathways and consequently less nutrient rich soil layers are drained. For N, it is unlikely that changes in denitrification activity will affect this mechanism, as the magnitude of denitrification was hardly affected by groundwater level. Notably, vast amounts of degradable organic matter were found throughout the soil profile and consequently groundwater level determined the depth of major denitrification activity, but had little effect on the total magnitude of $\mathrm{N}$ losses through denitrification (Van Beek et al. 
2004b). For P however, the topsoil is enriched by yearlong application of fertilizers and manure and increasing groundwater levels will result in increased desorption of P (Schoumans and Groenendijk 2000) and probably in increased $\mathrm{P}$ leaching losses for some time.

Raised water tables reduce mineralization of soil organic matter of peat soils (Best and Jacobs 1997; Schothorst 1977) and consequently decrease subsidence. However, the bearing capacity and temperature of the soil will also decrease causing less productive agriculture. In general, farmers are reluctant to raising surface water levels, but recently some promising results were achieved in the Northern peat soils of The Netherlands where, however, surface water levels are generally lower than in the Western peat soils of The Netherlands (Hoekstra et al. 2005). Moreover, farmers might adapt their fertilizer applications under a regime of raised surface water. Hence, the net effect of raised water tables on nutrient loading to surface water is the result of interactions between adjustments in fertilizer applications, biochemical responses and hydrological pathways. The responses to changes in water level may differ for the various nutrients. Drexler and Bedford (2002) concluded that for N and $\mathrm{Ca}$ groundwater was the main pathway of nutrient loading in a peat land area, whereas $\mathrm{P}$ and $\mathrm{K}$ were predominantly transported by overland flow. For the Vlietpolder surface-runoff was measured for $\mathrm{N}$ and $\mathrm{P}$ using catchment plates and yielded $1.30 \pm 0.76 \mathrm{~kg} \mathrm{~N}$ $\mathrm{ha}^{-1} \mathrm{y}^{-1}$ and $0.11 \pm 0.03 \mathrm{~kg} \mathrm{P} \mathrm{ha}{ }^{-1} \mathrm{y}^{-1}$ (Van Beek et al. 2003b), which is equivalent to, respectively, 3.4 and $5.5 \%$ of the annual $\mathrm{N}$ and $\mathrm{P}$ leaching losses. These results support the conclusions of Drexler and Bedford (2002) that for P overland transport is more important than for $\mathrm{N}$.

The groundwater samples in the Vlietpolder were classified as suboxic or Fe-anoxic $\mathrm{pH}$ neutral to slightly acid and Ca-saturated using the methodology of Graf Pannatier et al. (2000). This groundwater type is common for areas with a Holocene toplayer with clay or peat (personal communication van der Grift, 2004). About $35 \%$ of the peat soils in the western part of The Netherlands were created under eutrophic conditions (estimated after Pons 1992) and consequently shallow nutrient rich peat layers as found in the experimental field of the Vlietpolder are expected in more locations. This suggests that conclusions from this study seem valid for many peat areas in the western part of The Netherlands.

\section{Conclusions}

In many polders in the western part of The Netherlands eutrophic peat layers and marine clays are present at shallow depth. The results of this study suggest that these layers largely determined the composition of the soil solution and subsequently contributed to the $\mathrm{N}$ and $\mathrm{P}$ loading of surface water. Rising surface water levels can suppress this contribution with more than $30 \%$ for $\mathrm{Cl}$ and presumably also for $\mathrm{N}$, but for $\mathrm{P}$ the consideration with increased desorption is unclear.

Acknowledgements Kees Meinardi of RIVM is kindly acknowledged for critically reading the previous version of this paper. This project was funded by Rijnland Water Board, Ministry of Agriculture, Nature and Food Quality (LNV 398II), Ministry of Spatial Planning, Housing and Environment, STOWA, RIZA and the Province of South Holland.

\section{References}

Best, E. P. H., \& Jacobs, F. H. H. (1997). The influence of raised water table levels on carbon dioxide and methane production in ditch-dissected peat grasslands in The Netherlands. Ecological Engineering, 8, 129-144.

Bollmann, A., \& Conrad, R. (1997). Acetylene blockage technique leads to underestimation of denitrification rates in oxic soils due to scavenging of intermediate nitric oxide. Soil Biology \& Biochemistry, 29-7, 1067-1077.

Bussink, D. W. (1992). Ammonia volatilization from grassland receiving nitrogen fertilizer and rotationally grazed by dairy cattle. Fertilizer Research, 33, 257-265.

Corwin, D. L. (2002). Suction cups. In J. H. Dane \& G. C. Topp (Eds.), Methods of soil analysis. Part 4: Physical analysis (pp. 1261-1266). Madison: SSSA.

Davis, J. C. (1986). Statistics and data analysis in geology. New York: Wiley.

De Boer, T. A. (1982). The use of peat soils for grassland. Paper presented at the symposium on peat lands below sea level ILRI, pp. 214-221.

De Klein, C. A. M., \& Logtestijn, R. S. P. (1994). Denitrification in the top soil of managed grasslands in The Netherlands in relation to soil type and fertiliser level. Plant and Soil, 163, 33-44.

Drexler, J. Z., \& Bedford, B. L. (2002). Pathways of nutrient loading and impacts on plant diversity in a New York peatland. Wetlands, 22, 263-281.

Droogers, P., van Dam, J. C., \& Loeve, R. (2005). Decreasing leaching of peat water; a $2 D$ analysis. FutureWater, Wageningen, The Netherlands. In Dutch.

Fraser, C. J. D., Roulet, N. T., \& Lafleur, M. (2001). Groundwater flow patterns in a large peatland. Journal of Hydrology, 246, 142-154.

Giller, K., \& Wheeler, B. (1986). Peat and peat water chemistry of a flood-plain fen in Broadland, Norfolk, U.K. Freshwater Biology, 16, 99-114. 
Graf Pannatier, E., Broers, H. P., Venema, P., \& van Beusekom, G. (2000). A new process-based hydro-geochemical classification of groundwater, application to The Netherlands national monitoring system. TNO-report NITG 00-143-B.

Heathwaite, A. L. (1990). The effect of drainage on nutrient release from fen peat and its implication for water quality A laboratory simulation. Water, Air and Soil Pollution, 49, 159-173.

Heathwaite, A. L. (1991). Solute transfer from drained fen peat. Water, Air and Soil Pollution, 55, 379-395.

Hoekstra, J. R., Bos, L., \& de Ruiter, H. R. G. (2005). FeanWetter-Buorkje - Experiments with higher summer surface water levels in the Frisian peat land area. http://www.clm.nl.

Koops, J. G., Oenema, O., \& van Beusichem, M. L. (1996). Denitrification in the top- and subsoil of grassland on peat soils. Plant and Soil, 1154, 1-10.

Koops, J. G., van Beusichem, M. L., \& Oenema, O. (1997). Nitrogen loss from grassland on peat soils through nitrous oxide production. Plant and Soil, 188, 119-130.

Meinardi, C. R. (2004). Transport of water and solutes from soil to surface water in the Vlietpolder. RIVM report $500003004 / 2005$.

Nilsson, T., \& Lundin, L. (1996). Effects of drainage and wood ash fertilization on water chemistry at a cutover peatland. Hydrobiologia, 335, 3-18.

Oenema, O., \& Heinen, M. (1999). Uncertainties in nutrient budgets due to biases and errors: CABI. Wageningen, The Netherlands.

Peverly, J. H. (1982). Stream transport of nutrients through a wetland. Journal of Environmental Quality, 11, 38.

Pons, L. J. (1992). Holocene peat formation in the lower parts of The Netherlands. In J. T. A. Verhoeven (Ed.), Fens and bogs in TheNetherlands: Vegetation, history, nutrient dynamics and conservation (pp. 7-79). The Netherlands: Kluwer.

Poot, A., \& Schot, P. (2000). Rainwater lenses; shape and dynamics. Stromingen, 6(4), 13-26.

Pratt, P. F. (1978). Leaching of cations and chloride from manure applied to an irrigated soil. Journal of Environmental Quality, 7, 513-516.

Reijneveld, J. A., Habekotté, B., Aarts, H. F. M., \& Oenema, J. (2000). 'Typical Dutch'; View on the diversity of the Dutch dairy farming. Plant Research International report no. 8, Wageningen, The Netherlands. In Dutch.
RIVM (2002). MINAS en Milieu, Balans en Verkenning. in Dutch.

Schothorst, C. J. (1977). Subsidence of low moor peat soils in western Netherlands. Geoderma, 17, 265-291.

Schoumans, O. F., \& Groenendijk, P. (2000). Modelling soil phosphorus levels and phosphorus leaching from agricultural land in The Netherlands. Journal of Environmental Quality, 29, 111-116.

Simunek, J., Sejna, M., \& van Genuchten, M. Th. (1999). The HYDRUS-2D software package for simulating two-dimensional movement of water, heat, and multiple solutes in variably saturated media. Version 2.0, IGWMC-TPS-53, International Ground Water Modeling Center, Colorado School of Mines, Golden, Colorado, p. 251.

Van Beek, C. L., Brouwer, L., \& Oenema, O. (2003a). The use of farmgate balances and soil surface balances as estimator for nitrogen leaching to surface water. Nutrient Cycling in Agroecosystems, 67, 233-244.

Van Beek, C. L., Eertwegh van den, G. A. P. H., Schaik van, F. H., \& Toorn van den, A. (2003b). In: Surface runoff from intensively managed grassland on peat soils; a diffuse source of nitrogen and phosphorus in surface waters. Paper presented at the conference on diffuse input of chemicals into soil and groundwater, Dresden, Germany.

Van Beek, C. L., Hummelink, E. W. J., Velthof, G. L., \& Oenema, O. (2004a). Nitrogen losses through denitrification from an intensively managed grassland on peat soil. Biology and Fertility of Soils, 39(5), 329-336.

Van Beek, C. L., Van den Eertwegh, G. A. P. H., Van Schaik, F. H., Velthof, G. L., \& Oenema, O. (2004b). The contribution of dairy farming on peat soil on $\mathrm{N}$ and $\mathrm{P}$ loading of surface water. Nutrient Cycling in Agroecosystems, 70, 85-95.

Velthof, G. L., Koops, J. G., Duyzer, J. H., \& Oenema, O. (1996). Prediction of nitrous oxide fluxes from managed grassland on peat soil using a simple empirical model. Netherlands Journal of Agricultural Science, 44, 339356.

Wassen, M. J., \& Joosten, J. H. J. (1996). In search of a hydrological explanation for vegetation changes along a fen gradient in the Biebrza Upper Basin (Poland). Vegetatio, 124(2), 191-209.

Wieder, R. K., \& Lang, G. E. (1984). Influence of wetlands and coal mining on stream water chemistry. Water, Air and Soil Pollution, 23, 381. 